\title{
Identification of Dominant Factors in Choosing Diploma Programs in Undiksha
}

\section{Ni Wayan Marti ${ }^{*}$, Agus Aan Jiwa Permana²}

1,2 Informatics Management, Faculty of Engineering and Vocational, Universitas Pendidikan Ganesha

A R T I C L E I N F O

Article history:

Received 29 December 2019

Received in revised

Form 01 January 2020

Accepted 18 January 2020

Available online 28

February 2020

\section{Keywords:}

Dominant Factors,

Diploma Program,

Undiksha Campus

\section{A B S T R A C T}

This study aims to identify the dominant factors related to the interest of prospective students in choosing diploma study programs at the Ganesha Educational University (Undiksha). This research is quantitative descriptive. The method used is a survey method, targeting high school / vocational high school students, and parents of students. Data collection, with the distribution of questionnaires in the region of Buleleng and surrounding areas. There are seven variables used, namely: product, education costs, location, environment, promotion, individual and social economy. The results of the questionnaire were 88 respondents who were high school students, 57 respondents were vocational students, and 68 respondents were parents. Based on the results of data analysis, it was found that the selection of diploma study programs in Undiksha was influenced by several factors such as Products (80.75\%), Education (67.29\%), Location (68.08\%), Environment (41.78\%), Promotion (53.99)\%, Individual (65.73\%), and Social Economy (78.40\%). 


\section{Introduction}

Campus is an education level that must be passed by someone to get a job or an adequate position, in order to raise their standard of living. Through higher education, these millennial generations will not only form hardskill obtained through formal learning, but also soft skills obtained through student or student organizations that have been accommodated and provided by each of these campuses. High school students who will graduate later, of course, will continue their studies to campuses that have a good image in the community.

Therefore, the accreditation of a campus really determines high school graduates to consider their choice to enter college. Not only universities, the accreditation of study programs is also very influential in determining the interests of students and parents to choose the study program. Because to apply for a job, companies will see the accreditation of the study program where the prospective employee graduated.

Not only accreditation, many public perceptions about employment opportunities become one of the considerations in the selection of study programs. At present, the public is more interested in S1 education level education programs compared to diploma level study programs. The community is of the opinion that employment opportunities for graduates of extensive education, in fact state-owned / private companies need diploma graduates to work in companies.

Therefore, more and more graduates with bachelor's degrees in education find it difficult to get a job. Until now, diploma study programs especially in Undiksha are less interested than people in Bali. Because people tend to look more to continue their education to diploma strata study programs on public or private campuses in addition to Undiksha. There are certainly factors that cause the Balinese people to not choose a diploma strata study program at Undiksha. These factors include intrinsic factors (from within) and extrinsic factors (from outside).

From the explanation of the problem above, the researcher will conduct a study with the title "Identification of Dominant Factors in the Selection of Diploma Study Programs at Undiksha". This study aims to see what factors can increase the interest of parents and students in determining the selection of diploma strata study programs. In addition this research can increase the interest of high school/ vocational students to enroll in diploma strata study programs especially in Undiksha.

\section{Methods}

In this study, there are several methods that can be done such as exploring the description of interest in work, entrepreneurship, and continuing studies (Permana, et al., 2017). Then it needs to be grouped factors that influence the interest of college to diploma III programs, such as imaging promotion, service quality (Nugroho, 2010). This is due to the fact that vocational education is still underestimated for socializing matters at the workplace, even for student activities (Febrian, 2018). This has led to a decrease in the number of those interested in diploma programs (Amarul, 2017). So through this research, it aims to increase the number of prospective students who are interested in the diploma program by setting several variables such as purchasing decisions, prices, products, places, and promotions. The expected result is to increase the number of students who enroll in the diploma program (Risnawati and Irwandi, 2012) and know the amount of interest in continuing to the diploma program based on several influencing factors, namely factors within oneself, family environmental factors, and school environment.

\section{Diploma Study Program}

In RI Law SISDIKNAS Number 20 Year 2003 article 19 paragraph 1 Higher education is the level of education after secondary education which includes diploma, bachelor, master, specialist, and doctoral education programs organized by universities. In Indonesia, higher education can be divided into two. First, academic education which leads to the mastery of science. Second, prioritizing graduates to apply their expertise specifically obtained from vocational education. Vocational education is a higher education diploma program that prepares students to have certain applied skills up to the applied undergraduate program. Vocational education is education with the main goal of preparing to work using a competencybased education approach (Pavlova, 2009). With the diploma program, high school and equivalent graduates can develop their skills and reasoning in the application of science and technology. Therefore students have the skills and are ready to enter the workforce in accordance with their respective fields of expertise.

The diploma study program is a study program included in vocational education, which means the diploma program prioritizes soft skills knowledge rather than hard skills knowledge. This soft skill knowledge will later be very useful and more often applied at work later. The D3 study program has a three-year college period. In this D3 program, students are required to produce a unique product to 
qualify as an Associate Expert (A.Md). This scientific work is usually called the Final Project which is a requirement for student graduation. The courses offered in this diploma program are more practices that will hone the skills of students who are ready to enter the world of industry or business.

\section{Factors Affecting Interest}

Interest is a mental unit that results in a person having the potential to have a combination of feelings that lead a person to a choice of interest (Sukardi, 1994). Interest is where a condition and situation in accordance with the needs expected. Thus the notion of interest is the desire from within a person to have a sense of attraction and feeling happy about something that is chosen. If someone is interested in an object, it can be seen from the way a person acts, pays attention and does activities on that object.

In the research, identification of dominant factors in the selection of diploma study programs in Undikhsa is more leading to the factors that most determine the community in choosing a diploma study program in Undiksha. The following factors play a role, namely product, price, place, environment, promotion, individual and social economy. The following are factors that influence these interests, among others.

a. Product

Product is anything that can be offered by producers to the market to bind consumers so that the product can be bought, used, or consumed and that can meet the wants and needs of consumers (Kotler and Armstrong, 2001).

b. Price

Price is an economic sacrifice made by consumers in order to obtain a product or service. In addition, price is also an important factor for consumers to take action to make a transaction or not (Philip, 2008).

c. The place

Place or location is a place where an enterprise or business activity is located. The important factor in determining the place of business is the location of the place of business in urban areas and the distance to the place of business (Swastha, 2002).

d. Environment

The environment is all objects, conditions, conditions and influences contained in the room occupied and affects living things including life (Otto, 2004).

e. Promotion

Promotion is one of the efforts of information flow that can be done to lure a person or organization which will later create an exchange in marketing (Swastha, 2000).

f. Individual

Individuals come from the Latin individual, which is a small unit that can not be divided again. According to the concept of individual sociology means humans who stand alone. Individuals as God's creatures which include themselves in body, taste, ratio, and harmony (Sujatmiko, 2014).

g. Social economy

Economy is a variety of ways used by a person or group of people in utilizing limited resources to obtain various kinds of products and commodities and distribute them so that they can be consumed by many people (Soekanto, 2001). 


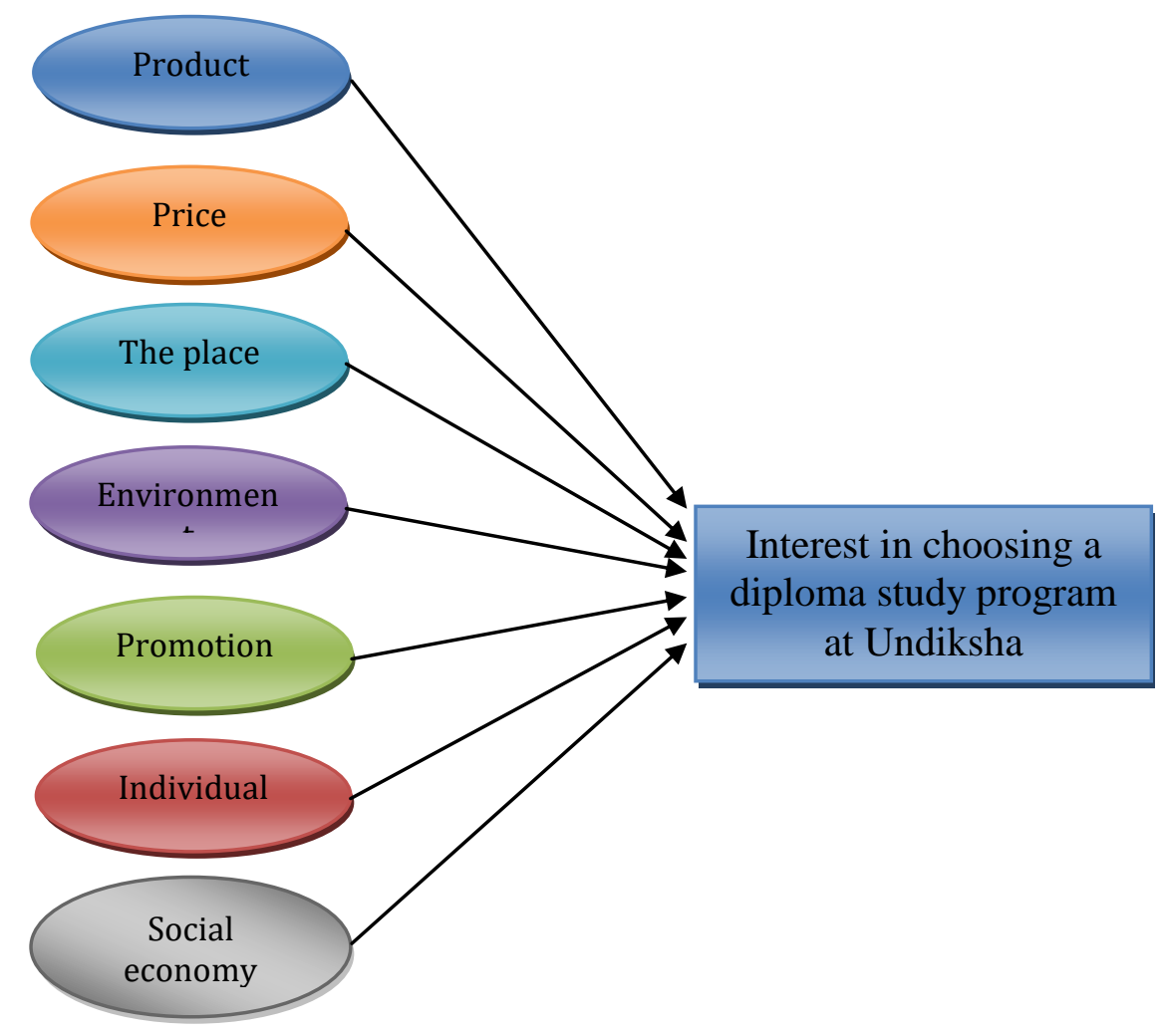

Figure 1. Framework for Thinking

\section{Framework of thinking}

Thinking framework is a conceptual model that explains how the relationship between theory and various factors that have been identified as important (Sekaran, 2006). Thus, understanding the framework of thinking is an understanding that underlies a process of research conducted. A good thinking framework will specifically describe the relationships between the variables studied.

The study was conducted to find a truth from the existing problems. The research process is carried out in various ways according to research needs. The results obtained are expected to be able to answer the problems that exist in the community and can be useful.

In general, the framework of thinking is only used in quantitative research. Therefore, research on the identification of dominant factors in the selection of diploma study programs at Undiksha uses a framework of thinking to find out how much influence the independent variable has on the dependent variable. The independent variable in question is the product, education costs, location, environment, promotion, individual, social economy. While the dependent variable in question is interest. Figure 1 will explain the research framework.

\section{Quantitative Descriptive Research}

Quantitative descriptive research is research that explains the phenomena that exist by using numbers to describe the characteristics of individuals or groups (Syamsudin and Damayanti, 2011). The purpose of this study is to describe the characteristics of things as they are.

This type of research is used in the study of identifying dominant factors in the selection of diploma study programs in Undiksha, namely using quantitative descriptive research structures that aim to provide an overview of the actual results related to the interests of students and parents of students in determining their choices in the diploma study program at Undiksha. Sukardi (2003) the steps in quantitative descriptive research are as follows.

a. Identify any significant problems that are used in descriptive methods.

b. Formulate and discuss problems

c. Determine research objectives and benefits.

d. Conducting literature studies related to research.

e. Designing research methods that will be used in this case is to determine population, samples, sampling techniques, data collection techniques, research instruments and data analysis.

1. Test instrument. 
2. Retrieval of data by distributing questionnaires to the study sample.

3. Analyze data.

4. Make a Research Report.

\section{Research subject}

Population is a unity of objects that will be examined later. In this research, identification of dominant factors in the selection of diploma study programs in Undiksha will take the population of parents of students and high school or vocational high school students in grade 3 in the province of Bali. The sample is part of a population that is considered to be representative of this population. In the research, identification of dominant factors in the selection of diploma strata in Undiksha took samples from parents of students and high school or vocational high school students in grade 3 in the city of Singaraja and its surroundings.

\section{Data Collection Procedure}

Data collected was obtained through questionnaires and interviews. With the time the study began in October 2018 until June 2019. This study uses two data sources, namely primary data and secondary data. Primary data sources of research obtain data from data collection techniques using a questionnaire that has been distributed directly to respondents. Secondary data sources are data that are used to supplement existing data. Additional data used in this study are journals, articles and sites from the internet related to research.

Data collection techniques used in the study identified the dominant factors in the selection of diploma study programs in Undiksha, namely random sampling by distributing questionnaires. Data that was collected through questionnaires and interviews were used as research material.

In this study, researchers used a closed-type questionnaire (Close Ended Questionnaire) which provides advantages for the researcher and the respondent. The advantage of a closed questionnaire is that it makes it easy for researchers to carry out the process of tabulating and analyzing data quickly, and can use software on computers that can simplify work and minimize costs. This type of questionnaire also makes it easy for respondents to answer every question / statement that has been available (Firdaus, 2012).

This interview technique is used by researchers to collect data whose questions have been designed in such a way, and then the questions are asked face-to-face to the respondent / resource persons one by one in detail.

\section{Research Instrument Development Procedure}

This study uses instruments for research tools that need to be designed with regard to the conditions in the preparation of the instrument. To obtain data in this study used a questionnaire to measure product variables, price, place, environment, promotion, individual, and socioeconomic. This research uses a closed questionnaire type, namely by choosing one alternative answer from the statement or question available.

This study uses the instrument lattice as a reference in order to facilitate the process of making questions or statements on the questionnaire. There are 7 (seven) variables needed to attract interest in choosing diploma level study programs at Undiksha, namely product, price, place, environment, promotion, individual, and socioeconomic. The operational definitions of the seven variables are as follows. The variables that will be used in this study can be seen in Table 1.

a. Product is a score that includes the image, facilities, curriculum, accreditation and quality of graduates.

b. Prices are scores that include affordability, cost suitability and cost comparison.

c. Place is a score that includes location and place.

d. Environment is a score that includes family, the environment and friends.

e. Promotion is a score that includes brochures, advertisements and outreach.

f. Individual is a score that includes interest, motivation and interest / talent.

g. Socio-Economic is a score that covers the family economy.

Table 1. The operational definitions of the seven variables

\begin{tabular}{llll}
\hline Dimension & Variable Item & Indicator & Statement \\
\hline Interest in the community chose & & Image of diploma study program & P1 \\
to continue their studies to the & Product & Amenities & P2 \\
diploma level at Undiksha & Curriculum & P3 \\
& & Accreditation & P4 \\
\hline
\end{tabular}




\begin{tabular}{llll}
\hline Dimension & Variable Item & Indicator & Statement \\
\hline \multirow{4}{*}{ Prices } & Quality of Graduates & P5 \\
& Affordability of costs & P6 \\
& Cost matching & P7 \\
& Place & Comparison of costs & P8 \\
& Location & P9 \\
& Distance & P10 \\
& Environment & Family & P11, P12 \\
& & Surrounding environment & P13 \\
& Promotion & Brochure & P14, P15 \\
& Advertisement & P16 \\
& Socialization & P17 \\
& Individual & Motivation & P18 \\
& Sttraction & P19, P20 \\
& Socio-Economic & Interest talent & P21 \\
& & Family economy & P22,P23 \\
\hline
\end{tabular}

The form of statements used in this questionnaire are positive statements and negative statements. This is done so that respondents are careful in answering each statement and there is no consistency of answers (Malhotra, 2012). The lattice of instruments used in this study can be seen in Table 2.

Table 2. The lattice of instruments used in this study

\begin{tabular}{|c|c|c|c|c|c|}
\hline \multirow{2}{*}{ No. } & \multirow{2}{*}{ Variable Item } & \multirow{2}{*}{ Indicator } & \multirow{2}{*}{ Number of Que. } & \multicolumn{2}{|c|}{ No Quisionnaire } \\
\hline & & & & Positif & Negatif \\
\hline \multirow{5}{*}{1} & \multirow{5}{*}{ Product } & Image of diploma study program & 1 & 2 & - \\
\hline & & Amenities & 1 & 1 & - \\
\hline & & Curriculum & 1 & 4 & - \\
\hline & & Accreditation & 1 & 3 & - \\
\hline & & Quality of Graduates & 1 & 5 & - \\
\hline \multirow{3}{*}{2} & \multirow{3}{*}{ Prices } & Affordability of costs & 1 & 6 & - \\
\hline & & Cost matching & 1 & 7 & - \\
\hline & & Comparison of costs & 1 & 8 & - \\
\hline \multirow{3}{*}{3} & \multirow{3}{*}{ Place } & Location & 1 & 9 & - \\
\hline & & Distance & 1 & 10 & - \\
\hline & & Family & 2 & 11 & 12 \\
\hline \multirow[t]{3}{*}{4} & \multirow[t]{2}{*}{ Environment } & Surrounding environment & 1 & 13 & - \\
\hline & & Friend & 2 & 14,15 & - \\
\hline & \multirow{4}{*}{ Promotion } & Brochure & 1 & 16 & - \\
\hline \multirow[t]{3}{*}{5} & & Advertisement & 1 & 17 & - \\
\hline & & Socialization & 1 & 18 & - \\
\hline & & Motivation & 2 & 19,20 & - \\
\hline \multirow[t]{2}{*}{6} & \multirow[t]{2}{*}{ Individual } & Attraction & 1 & 21 & - \\
\hline & & Interest talent & 2 & 23 & 22 \\
\hline 7 & Socio-Economic & Family economy & 1 & 24 & - \\
\hline
\end{tabular}

Likert scale is a calculation used to calculate each item of questions or statements in this study. The use of the Likert scale aims to select 1 of the 5 answers used to measure indicators. The statements or questions used are positive $(+)$ and negative $(-)$ statements. 
Table 3. Giving scores to each answer option items

\begin{tabular}{llll}
\hline No. & Question Option & $\begin{array}{l}\text { Score } \\
\text { Positif (+) }\end{array}$ & Negatif (-) \\
\hline 1 & STS (Strongly Disagree) & 1 & 5 \\
2 & TS (Disagree) & 2 & 4 \\
3 & R (Doubtful) & 3 & 3 \\
4 & S (Agree) & 4 & 2 \\
5 & SS (Strongly Agree) & 5 & 1 \\
\hline
\end{tabular}

\section{Research Data Analysis Procedure}

Data analysis is a process of grouping data obtained from systematic data collection techniques based on variables that have been studied (Sugiyono, 2000). The sampling technique is carried out randomly, the data collection technique uses quantitative research methods that aim to test the hypothesis set. The results of the data collection will be further analyzed by calculating using descriptive statistics.

Descriptive statistics are statistics used to analyze data by describing data that has been obtained as is. Descriptive statistics to be calculated are the mean, median, mode, standard deviation of each variable.

In the study of identifying dominant factors in the selection of diploma study programs at Undikhsa the data analysis technique used is descriptive statistics. The purpose of the analysis in this study is to find out the dominant factors that influence the interests of students and parents of students in the selection of diploma study programs at Undiksha.

The instrument testing was carried out on each item contained in the research questionnaire. The trial of this instrument used the Validity Test conducted by 2 experts. The aim is to see the agreement of 2 experts in evaluating each statement item. The validity test results obtained can be seen in Table 4 .

Validity testing by 2 experts was carried out using the Gregory formula (Column D divided by A + B $+\mathrm{C}+\mathrm{D})$.

$$
V i=\frac{D}{A+B+C+D}
$$

Equation 1. of Gregory's formula

Information on Equation 1 :

$\mathrm{Vi}=$ Constructive Validation
$\mathrm{A}=$ Both rater disagree
$\mathrm{B}=$ Rater 1 agrees, rater 2 disagrees
$\mathrm{C}=$ Rater 1 disagrees, rater 2 agrees
$\mathrm{D}=$ Both rater agree

Table 4. THE VALIDITY TEST RESULTS

\begin{tabular}{|c|c|c|c|c|c|}
\hline \multirow{2}{*}{ No. } & \multirow{2}{*}{ Variable Item } & \multirow{2}{*}{ Indicator } & \multirow{2}{*}{ Number of Que. } & \multicolumn{2}{|c|}{ Validation } \\
\hline & & & & Drop & Valid \\
\hline \multirow{5}{*}{1} & \multirow{5}{*}{ Product } & Image of diploma study program & 1 & - & 2 \\
\hline & & Amenities & 1 & - & 1 \\
\hline & & Curriculum & 1 & - & 4 \\
\hline & & Accreditation & 1 & - & 3 \\
\hline & & Quality of Graduates & 1 & - & 5 \\
\hline \multirow{3}{*}{2} & \multirow{3}{*}{ Prices } & Affordability of costs & 1 & - & 6 \\
\hline & & Cost matching & 1 & - & 7 \\
\hline & & Comparison of costs & 1 & - & 8 \\
\hline \multirow{2}{*}{3} & \multirow{2}{*}{ Place } & Location & 1 & - & 9 \\
\hline & & Distance & 1 & - & 10 \\
\hline
\end{tabular}




\begin{tabular}{|c|c|c|c|c|c|}
\hline \multirow{2}{*}{ No. } & \multirow{2}{*}{ Variable Item } & \multirow{2}{*}{ Indicator } & \multirow{2}{*}{ Number of Que. } & \multicolumn{2}{|c|}{ Validation } \\
\hline & & & & Drop & Valid \\
\hline \multirow{3}{*}{4} & \multirow{3}{*}{ Environment } & Family & 2 & - & 11,12 \\
\hline & & Surrounding environment & 1 & - & 13 \\
\hline & & Friend & 2 & - & 14,15 \\
\hline \multirow{3}{*}{5} & \multirow{3}{*}{ Promotion } & Brochure & 1 & - & 16 \\
\hline & & Advertisement & 1 & - & 17 \\
\hline & & Socialization & 1 & - & 18 \\
\hline \multirow{3}{*}{6} & \multirow{3}{*}{ Individual } & Motivation & 2 & - & 19,20 \\
\hline & & Attraction & 1 & - & 21 \\
\hline & & Interest talent & 2 & - & 22,23 \\
\hline 7 & Socio-Economic & Family economy & 1 & - & 24 \\
\hline
\end{tabular}

\section{Result And Discussion}

This research is a quantitative descriptive study that aims to find out the dominant factors that influence the interest of the general public towards the diploma strata study program at Ganesha University of Education (Undiksha). There are 7 (seven) factors that are used to measure people's interest in the diploma program at Undiksha, namely (1) products, (2) education costs, (3) location, (4) environment, (5) promotion, (6) individuals, (7) socioeconomic. The respondents used in this study were parents and high school and vocational high school students grade 3 (From Class 12). The data collection technique used is random sampling. The data used as samples in this study were 213 for consisting of 88 high school students, 57 vocational high school students and 68 parents of students. The distribution of this questionnaire was done offline and online. Questionnaire sheets were distributed throughout Bali but more data was obtained from distributions in the Regency of Buleleng. This is done because the distance is too far for distribution in other regencies other than Buleleng Regency in the Bali region.

Table 5. General Description For Each Variable

\begin{tabular}{clccccc}
\hline No. & \multicolumn{1}{c}{ Variable } & Item & Score Maximum & Score Minimum & Mean & Standard Deviation \\
\hline 1 & Product & 5 & 25 & 12 & 20.15 & 2.76 \\
2 & Cost of education & 3 & 15 & 7 & 11.37 & 1.68 \\
3 & Location & 2 & 10 & 3 & 7.52 & 1.59 \\
4 & Environment & 5 & 24 & 8 & 15.53 & 2.75 \\
5 & Promotion & 3 & 15 & 3 & 10.41 & 2.23 \\
6 & Individual & 5 & 25 & 9 & 18.40 & 2.69 \\
7 & Social economy & 1 & 5 & 1 & 3.92 & 0.85 \\
\hline & & & & & & $* \mathbf{N}=\mathbf{2 1 3}$
\end{tabular}

In this section a descriptive statistical analysis will be carried out to find out the mean, median, mode and standard deviation of each variable. Questionnaire data collected is processed simply using Microsoft Excel software. This data processing is done to determine the tendency of the quality of each variable. General description for each variable can be seen in Table 5. To provide a more specific general picture, the following will be explained about each variable, including: product, education costs, location, environment, promotion, individual and socio economic.

\section{Product Factor Analysis}

Percentage of statement items for product variables from the results of data tabulation using 213 samples in the general public, especially high school / vocational high school students and parents of students in the city of Singaraja and surrounding areas. If seen from the results of the tabulated data, that further explanation of the results of the percentage of statements using product variables is as follows:

a. As many as $82.63 \%$ of respondents agreed that the image of the diploma study program at Undiksha affected the interests of the community, while as many as $17.37 \%$ of respondents said they did not agree.

b. $80.75 \%$ of respondents stated that the supporting facilities provided at Undiksha were adequate, while $19.25 \%$ of respondents stated that the facilities provided at Undiksha were inadequate. 
c. As many as $76.53 \%$ of respondents stated that the curriculum offered had provided good competence to graduates, while as many as $23.47 \%$ of respondents stated that the curriculum offered had not had a good impact on graduates.

d. $83.10 \%$ of respondents stated that they would continue their studies to the diploma level in Undiksha because of their accreditation, while as many as $16.90 \%$ of respondents stated that they would not continue their studies to the diploma level in Undiksha because of accreditation.

e. As many as $80.75 \%$ of respondents stated that they were interested in continuing their study to the diploma level in Undiksha because they were seen from highly qualified graduates, while $19.25 \%$ of respondents stated that they were not interested in continuing their study to the diploma level at Undiksha because they were seen from their graduates.

From the average percentage value of the items included in the product variable, $80.75 \%$ was obtained stating that the product variable had an influence in determining the community's interest to choose the study program. The product referred to in the research is related to facilities, image, accreditation, curriculum, and graduate quality. Based on the information above, it can be concluded that the interest of the community to continue their studies to the diploma level at Undiksha can be seen from: a) image owned by the Undiksha diploma study program, b) the facilities provided are adequate, c) the curriculum offered can provide good competence to graduates, d) good accreditation of study programs, and e)quality of graduates.

\section{Cost of education Factor Analysis}

Each statement gets the following percentage results : 1) As many as $65.25 \%$ of respondents agreed that the costs needed to undertake diploma studies at undiksha were affordable, while as many as $34.74 \%$ of respondents stated that they disagreed with this, 2) As many as 76.06\% of respondents said that the fees determined were in accordance with the quality of the diploma study program, while as many as $23.94 \%$ of respondents said that the fees set did not match the quality of the diploma study program, 3) As many as $60.56 \%$ of respondents stated that the fees set in the diploma study program were lower than the S1 study program, while as many as $39.44 \%$ of respondents stated that the fees set in the S1 study program were lower.

From the detailed explanation above obtained an average of $67.29 \%$ of the community stated that the variable cost of education affects the community's interest in choosing diploma study programs. Based on the information above, it can be concluded that the interest of the community to continue their studies to the diploma level at Undiksha can be seen from: a. The small amount of funds needed for diploma strata study programs at Undiksha, b. The tuition fees are determined according to the quality of the diploma study program, c. The tuition fees set at the diploma study program are lower than the S1 study program.

\section{Location Factor Analysis}

The following are the results of data processing from the statement items on location variables.

a. As many as $76.53 \%$ of respondents agreed to choose to continue their studies to the diploma level in Undiksha because of the strategic location in the middle of the city, while $23.47 \%$ of respondents stated that they did not agree.

b. $60.09 \%$ of respondents said that they chose to continue their studies to the Undiksha diploma level because of their close distance, while $39.91 \%$ of respondents said that they did not choose to continue their studies at the Undiksha diploma level because of their close proximity.

From the average percentage value of items included in the location variable, $68.08 \%$ of the community stated that the location variable had an effect on determining the community's interest in choosing the study program. The location referred to in the study is related to location and distance. Based on the data above, it can be concluded that the interest of the community to continue their studies to the diploma level at Undiksha can be seen from: a. Undiksha's strategic location in the middle of the city, and b. close distance to Undiksha.

\section{Environment Factor Analysis}

Based on the results of the processing of bullet points for environmental variables obtained the following results.

a. As many as $42.96 \%$ of respondents said that choosing to continue their studies to a diploma study program was influenced by family factors, while as many as $57.04 \%$ of respondents stated that they chose to continue to study diploma strata because of their own desires. 
b. As many as $57.75 \%$ of respondents said that continuing diploma studies at Undiksha was due to the influence of support from people around other than family, while as many as $42.25 \%$ of respondents said that continuing diploma studies at Undiksha was not influenced by the support of people around.

c. As many as $24.65 \%$ of respondents said that they chose to continue their studies to the diploma level at Undiksha due to the influence of friends, while $75.35 \%$ of respondents were influenced by personal factors.

From the average percentage value of the items included in the environmental variable, it was found that as many as $41.78 \%$ of the community stated that the environmental variable had an influence in determining the community's interest to choose the study program. The environment referred to in the study is related to family, the environment, friends. Based on the data above, it can be concluded that the community's interest to continue their studies to the diploma level at Undiksha is due to the following factors: a. family wishes, b. full support from the family, c. support from people around, d. the number of friends who continue their diploma level studies at Undiksha, e. invitation from friends.

\section{Promotion Factor Analysis}

The percentage of statement items for the promotion variable from the results of data tabulation using 213 samples in the general public especially high school / vocational high school students and parents of students in the City of Singaraja and its surroundings is.

a. As many as $51.64 \%$ of respondents stated that they chose to continue their studies to a diploma study program because they saw the brochure distributed, while $48.36 \%$ of respondents said that they did not see the brochure distributed.

b. As many as $55.40 \%$ of respondents said that they chose to continue their studies to the diploma level because they saw advertisements spread on the internet, especially on social media, while $44.60 \%$ of respondents said that they did not see any advertisements that were spread on the internet, especially on social media.

c. As many as $54.93 \%$ of respondents said that they continued their diploma studies at Undiksha because of socialization at school, while $45.07 \%$ of respondents said that they did not continue their diploma studies at Undiksha because of socialization at school.

From the average percentage value of the items included in the promotion variable, $53.99 \%$ of the community stated that the promotion variable had an influence in determining the community's interest to choose the study program. The promotion referred to in the research is related to brochures, advertisements, outreach. Based on the data above, it can be concluded that the interest of the community to continue their studies to the diploma level at Undiksha can be seen from: a. distributed brochure, $b$. advertisements spread on the internet especially on social media, and c. there is socialization in schools.

\section{Individual Factor Analysis}

The percentage of statement items for individual variables from the results of tabulation of data using 213 samples in the general public, especially high school / vocational students and parents of students in the city of Singaraja and its surroundings is. a) As many as $72.07 \%$ of respondents stated that continuing their studies to the diploma level was influenced by great motivation, b) $72.30 \%$ of respondents said that the diploma study program at Undiksha was quite superior among other study programs, and c) As many as $52.82 \%$ of respondents said that they wanted to continue their studies to the diploma level because they were influenced by the interests / talents of candidates.

From the average percentage value of items included in individual variables, $65.73 \%$ of the community stated that the individual variables were influential in determining community interest in choosing study programs. Individuals referred to in research are related to motivation, interest, interest / talent. Based on the data above, it can be concluded that the interest of the community to continue their studies to the diploma level at Undiksha can be seen from: a. the need for workers who have special (professional) skills and expertise obtained through diploma education, b. the excellence of Dipoma Study Program at Undiksha is quite superior among other study programs, c. according to ability, and d. short diploma strata study period.

\section{Social Economy Factor Analysis}

The results of the data tabulation are carried out, that further explanation of the results of the percentage of statements using socioeconomic variables is as many as $78.40 \%$ of respondents said they agreed to choose a particular study program, first they had to look at the income received by parents, 
while $21.60 \%$ of respondents said that they did not agree. based on the data above, it can be concluded that the interest of the community to continue their studies to the diploma level in undiksha must first look at the economic condition of the family.

\section{Conclussion}

This research is a quantitative descriptive study using a survey method used to measure people's interest in continuing their studies to the diploma level at Undiksha. This study took data from high school / vocational high school students grade 3 and parents of students in the region of Buleleng and surrounding areas. The data collection technique used was the distribution of questionnaires which were carried out randomly to respondents. There are seven variables used to measure people's interest in choosing diploma study programs in Undiksha, namely product, education costs, location, environment, promotion, individual and socioeconomic.

The results of the questionnaire distribution, 88 respondents were high school students, 57 respondents were vocational school students, and 68 respondents were parents. The results of data analysis, it was found that the selection of diploma study programs in Undiksha was influenced by product factors as much as $80.75 \%$, Educational factors as much as $67.29 \%$, location factors as much as $68.08 \%$, environmental factors as much as $41.78 \%$, factors promotion $53.99 \%$, individual factors as much as $65.73 \%$, and socioeconomic factors as much as $78.40 \%$. From this description, it can be said that the promotion factor has a less significant influence so that efforts from Undiksha are needed to conduct better and scheduled promotions and outreach.

Based on the research results obtained, that there needs to be a lot of further research that must be done to get clearer results. It is necessary to expand the area for distributing questionnaires such as outside Bali, such as in East Java, Lombok and surrounding areas. The need for more regular and scheduled promotions and outreach so that the existence of study programs at Undiksha is more clearly known by the public.

\section{Reference}

Amarul. (2017). Analisis Persepsi Keputusan Memilih Program Studi Diploma III Jurusan Ekonomi Pada Universitas Serang Raya (Tinjau Dari Marketing Mix). Jurnal Sains Manajemen, Vol III.

Febrian, R., 2018, Nasib Pendidikan Vokasi yang Masih Dipandang Sebelah Mata, https://tirto.id/nasibpendidikan-vokasi-yang-masih-dipandang-sebelah-mata-cPGw, (diakses : 14 Feb 2019)

Firdaus, M. (2012). Metode Penelitian. Tangerang: Jelajah Nusa.

Kotler, \& Amstrong. (2001). Prinsip-Preinsip Pemasaran. Jakarta: Erlangga.

Malhotra, M. K. (2012). Operations Management. USA: Pearson.

Nurtanto, M., \& dkk. (2017). Faktor Pengaruh Minat Masuk Perguruan Tinggi di SMK Serang. Jurnal Pendidikan Teknologi dan Kejuruan, Vol. 14, 11.

Nugroho, C.S, 2010, Analisis Pengaruh Pencitraan, Promosi, Dan Kualitas Pelayanan Terhadap Minat Kuliah Di Diploma III, Fakultas Ekonomi Universitas Diponegoro, Skripsi, Fakultas Ekonomi Universitas Diponegoro Semarang

Otto, S. (2004). Lingkungan Hidup dan Pembangunan. Jakarta: Djambatan.

Pavlova, M. (2009). Thecnology and Vocational education for sustainable development: Empowering individuals for the future. Australia: Springer.

Permana, R.A, Permana, T., Sasmita, A.H, 2017, Eksplorasi Minat Bekerja, Berwirausaha, Dan Melanjutkan Studi Mahasiswa Program Studi Teknik Mesin UPI, Journal of Mechanical Engineering Education, Vol. 4, No. 1, Juni 2017

Philip. (2008). Manajemen Pemasaran Edisi 12 Jilid 2. Jakarta: Indeks. 
Risnawati, \& Irwandi, S. A. (2012). Risnawati dan Soni Agus Irwandi. 2012. Analisis Faktor Atas Pengambilan Keputusan Mahasiswa Untuk Memilih Jurusan Akuntansi Di STIE Perbanas Surabaya. Surabaya: The Indonesian Accounting Review. Vol. 2, No. 1 2012. The Indonesian Accounting Review, Vol II.

Sekaran, U. (2006). Metodologi Penelitian untuk Bisnis. Jakarta: Salemba Empat.

Soekanto, S. (2001). Sosiologi. Jakarta: PT Rajagrafindo Persada.

Sugiyono. (2000). Metode Penlitian Pendidikan. Bandung: Alfabeta. 